\title{
Potential of Ramalin and Its Derivatives for the Treatment of Alzheimer's Disease
}

\author{
Tai Kyoung Kim ${ }^{1,+}$, Ju-Mi Hong ${ }^{1,+} \mathbb{C}$, Kyung Hee Kim ${ }^{1,2}$, Se Jong Han ${ }^{1}$, Il-Chan Kim ${ }^{1}$, Hyuncheol Oh ${ }^{3}$ and \\ Joung Han Yim ${ }^{1, *}$
}

1 Division of Polar Life Sciences, Korea Polar Research Institute, Incheon 21990, Korea; tkkim@kopri.re.kr (T.K.K.); wnal5555@kopri.re.kr (J.-M.H.); kh313@kopri.re.kr (K.H.K.); hansj@kopri.re.kr (S.J.H.); ickim@kopri.re.kr (I.-C.K.)

2 Department of Chemistry, Hanseo University, Seosan 31962, Korea

3 College of Pharmacy, Wonkwang University, Iksan 54538, Korea; hoh@wcu.ac.kr

* Correspondence: jhyim@kopri.re.kr; Tel.: +82-32-760-5540; Fax: +82-32-760-5509

+ These authors contributed equally to this study.

check for updates

Citation: Kim, T.K.; Hong, J.-M.; Kim, K.H.; Han, S.J.; Kim, I.-C.; Oh, H.; Yim, J.H. Potential of Ramalin and Its Derivatives for the Treatment of Alzheimer's Disease. Molecules 2021, 26, 6445. https://doi.org/10.3390/ molecules26216445

Academic Editor: Federica Belluti

Received: 13 September 2021

Accepted: 20 October 2021

Published: 26 October 2021

Publisher's Note: MDPI stays neutral with regard to jurisdictional claims in published maps and institutional affiliations.

Copyright: (c) 2021 by the authors. Licensee MDPI, Basel, Switzerland. This article is an open access article distributed under the terms and conditions of the Creative Commons Attribution (CC BY) license (https:// creativecommons.org/licenses/by/ $4.0 /)$.

\begin{abstract}
The pathogenesis of Alzheimer's disease (AD) is still unclear, and presently there is no cure for the disease that can be used for its treatment or to stop its progression. Here, we investigated the therapeutic potential of ramalin (isolated from the Antarctic lichen, Ramalina terebrata), which exhibits various physiological activities, in AD. Specifically, derivatives were synthesized based on the structure of ramalin, which has a strong antioxidant effect, BACE-1 inhibition activity, and anti-inflammatory effects. Therefore, ramalin and its derivatives exhibit activity against multiple targets associated with AD and can serve as potential therapeutic agents for the disease.
\end{abstract}

Keywords: Alzheimer's disease; ramalin; derivatives; therapeutic potential; antioxidant; $\beta$-secratase; anti-inflammatory

\section{Introduction}

In 2016, the number of patients with dementia worldwide was 23.8 million, and this number is increasing every year owing to population aging and growth. Thus, caregiving and support for patients with dementia have far-reaching implications for families, health systems, and society as a whole [1,2]. Dementia is known to be associated with a shortened life expectancy, and this makes it the fifth leading cause of death in developed countries [3]. Further, Alzheimer's disease (AD), which accounts for more than half this number of deaths, is the most common cause of dementia. Patients diagnosed with AD show progressively worsening symptoms, including memory disorders, speech disorders, spatiotemporal disorders, and mental disorders, including delusions and hallucinations. Furthermore, the pathogenesis of $\mathrm{AD}$ is diverse and complex. Low acetylcholine $(\mathrm{ACh})$ concentrations in the synaptic cleft, amyloid beta $(\mathrm{A} \beta)$ peptide aggregation and accumulation, tangles of microtubule-associated protein tau, and oxidative stress are considered to be the main causes of $\mathrm{AD}$. It has also been observed that $\mathrm{A} \beta$ aggregation and accumulation in the brain can be the result of increased $A \beta$ production, decreased $A \beta$ protease activity, or altered $\mathrm{A} \beta$ transport across the blood-brain barrier (BBB) [4]. Additionally, $\beta$-site APP-cleaving enzyme 1 (BACE-1), which is associated with an increase in $A \beta$ production, is considered a target for the prevention and treatment of $\mathrm{AD}$ [5]. It has also been observed that $A \beta$ is produced via the sequential cleavage of amyloid precursor protein (APP) by BACE- 1 and BACE-2, with BACE-1 being the key enzyme that initiates the process [6]. Experimental evidence based on studies involving human APP transgenic mice suggests that memory deficits can be prevented via BACE-1 gene deletion [7], and reportedly A $\beta$ aggregates can act as pathogenic mediators, inducing oxidative stress, neuroinflammation, and BACE-1 expression, which further exacerbate $\mathrm{AD}$ [8]. In addition to $\mathrm{A} \beta$ accumulation via $\mathrm{BACE}-1$, 
oxidative stress and inflammation can also enhance $A \beta$ production. In a study which showed the existence of an association between $\mathrm{A} \beta$ formation and inflammation, plaques were observed in the brains of monkeys with chronic inflammation [9]. Therefore, reducing inflammation based on the use of anti-inflammatory drugs could significantly lower the prevalence of $\mathrm{AD}$, given that inflammation enhances the production of reactive oxygen species (ROS), which cause oxidative damage to lipids, proteins, and nucleic acids [10]. Additionally, nuclear factor kappa-light-chain-enhancer of activated B cells (NF- $\mathrm{kB}$ ), which is related to inflammation, is involved in the expression of BACE-1, which is regulated by various mechanisms [11]. Thus, BACE-1, inflammation, and ROS are all related to A $\beta$ formation from the initiation of $\mathrm{AD}$ to the post-onset period.

From another perspective, ROS-induced oxidative stress has emerged as a factor in the development of $\mathrm{AD}$, and reportedly is responsible for the early onset and exacerbation of AD [12]. Mitochondrial ROS, which are produced under normal conditions, are balanced by antioxidants and related enzymes. However, dysfunction in this regard owing to oxidative injury results in the generation of high levels of ROS as well as the release of apoptosisinducing proteins [13-15]. Additionally, mitochondrial endoplasmic reticulum dysfunction owing to oxidative stress induces a cellular stress response known as the unfolded protein response (UPR) $[12,16,17]$, which can protect cells from the accumulation of toxic proteins, but can lead to neurodegeneration when sustained [14,18].

Ramalin, isolated from the Antarctic lichen, Ramalina terebrata, exerts potent antioxidant and antibacterial effects $[19,20]$. In our previous study, we investigated the various physiological activities of ramalin with the aim of developing it as a therapeutic agent for oxidation-related diseases, a functional food for anti-aging, and a functional cosmetic agent for whitening and wrinkle improvement [21]. Further, owing to its strong antioxidative power, it has also been shown to exhibit anti-inflammatory [22], lipid-accumulationreducing [23], and anti-hepatic fibrosis [24] activities. Its BACE-1 inhibitory effects as well as its antioxidant and anti-inflammatory effects have been confirmed, suggesting that it has potential as a therapeutic agent for AD treatment. In this study, we investigated its physiological activity based on the modification of its structure by synthesizing its derivatives (Figure 1), which were obtained by replacing the functional group (phenolic hydroxyl) on the phenyl ring with either a methyl group or a fluorine atom.

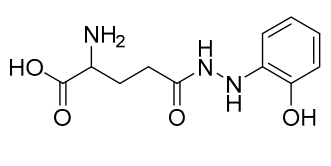

Ramalin<smiles>Cc1ccc(C)c(NNC(=O)CCC(N)C(=O)O)c1</smiles>

RA-25Me, $78 \%$<smiles>NC(CCC(=O)NNc1ccc(F)cc1F)C(=O)O</smiles>

RA-24F, 75\%

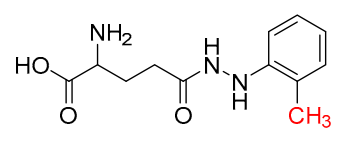

RA-2Me, $70 \%$<smiles>Cc1ccc(NNC(=O)CCC(N)C(=O)O)cc1C</smiles>

RA-34Me, $70 \%$

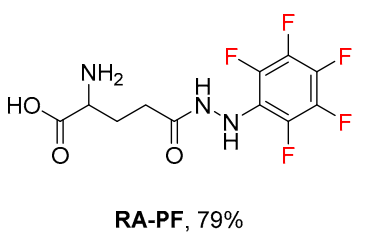<smiles>Cc1cccc(NNC(=O)CCC(N)C(=O)O)c1</smiles>

RA-3Me, $72 \%$<smiles>NC(CCC(=O)NNc1ccccc1F)C(=O)O</smiles>

RA-2F, $62 \%$<smiles>Cc1ccc(NNC(=O)CCC(N)C(=O)O)cc1</smiles>

RA-4Me, $67 \%$<smiles>NC(CCC(=O)NNc1ccc(F)cc1)C(=O)O</smiles>

RA-4F, $65 \%$

Figure 1. Structure of ramalin and its derivatives.

Owing to various setbacks, no cure for AD has been established thus far. Further, the pathogenesis of the disease is not fully understood, and there is no cure for the disease that can be used for its treatment or to stop its progression. Therefore, to address this problem, we investigated the potential of ramalin and its derivatives, which do not target 
only a specific mechanism of action but exhibit various physiological activities, such as antioxidant, anti-inflammatory, and BACE-1 inhibitory activities, as therapeutic agents for AD.

\section{Results}

\subsection{Synthesis of Ramalin and Its Derivatives}

Ramalin was successfully synthesized according to the method developed in our previous study [25]. The synthesis was conducted by coupling phenylhydrazine to 1benzyl- $\mathrm{N}$-Cbz-L-glutamic acid, the starting material. After lowering the temperature to $-5{ }^{\circ} \mathrm{C}$, triethylamine (TEA) and ethyl chloroformate (ECF) were sequentially added to the solution of the starting material dissolved in dichloromethane (DCM). Thereafter, the reaction mixture was stirred for approximately $2 \mathrm{~h}$, and while maintaining the temperature, hydrazine $\mathrm{HCl}$ salt was added to complete the coupling reaction. This was followed by the deprotection of the benzyl and benzyloxycarbonyl $(\mathrm{Cbz})$ groups using $\mathrm{Pd} / \mathrm{C}$ and $\mathrm{H}_{2}$ gas, after which the crude product was recrystallized to obtain ramalin. To obtain ramalin derivatives, similar reaction conditions were employed (Scheme 1).<smiles>O=C(O)CCC(NC(=O)O)C(=O)OCc1ccccc1</smiles>
$-5^{\circ} \mathrm{C}, 4 \mathrm{~h}$

ii) TEA, $-5^{\circ} \mathrm{C}$ to $\mathrm{RT}$, $16 \mathrm{~h}$<smiles>[R]c1ccc(NN)cc1</smiles>
hydrazines<smiles>[R]OC(=O)NC(CCC(=O)NNc1ccccc1)C(=O)OCc1ccccc1</smiles>

$\mathrm{R}=2-\mathrm{OH}$ (ramalin)

$\mathrm{R}=\mathrm{Me}(2 \mathrm{Me}, 3 \mathrm{Me}, 4 \mathrm{Me})$

$\mathrm{R}=\mathrm{Di}-\mathrm{Me}(25 \mathrm{Me}, 34 \mathrm{Me})$

$\mathrm{R}=\mathrm{F}(2 \mathrm{~F}, 4 \mathrm{~F})$

$\mathrm{R}=\mathrm{Di}-\mathrm{F}(24 \mathrm{~F})$

$\mathrm{R}=$ Penta-F $(\mathrm{PF})$

\section{RA-derivatives}

Scheme 1. Scheme showing the synthesis of ramalin and its derivatives.

Reportedly, when ramalin is in the form of a dry solid, it is stable at room temperature (i.e., $25^{\circ} \mathrm{C}$ ); however, in an aqueous solution, it is unstable and this is considered a disadvantage [26]. Through HPLC analysis, the change in purity of ramalin and its derivatives (10 $\mathrm{mM}$ in water) at room temperature was measured by UV absorbance at $254 \mathrm{~nm}$. The purity of ramalin decreased from $98 \%$ to $83 \%$ after $14 \mathrm{~h}$, but no change in purity was observed in the derivatives. Therefore, to improve its stability and BBB penetration capacity, its structure was modified by replacing the phenolic hydroxyl groups at position two with either a methyl group or a fluorine atom and by changing their positions. Thus, several derivatives were obtained. Specifically, RA-2Me, RA-3Me, and RA-4Me were synthesized by changing the position of the methyl group, which is an electron-donating group, and RA-25Me and RA-34Me, with two methyl groups on the phenyl ring, were synthesized by introducing an extra methyl group. To investigate the effect of fluorine atoms, which are electron-withdrawing as opposed to the methyl group, RA-2F, RA-4F, RA-24F, and RA-pentafluoride (PF) were also successfully synthesized. Additionally, given that ramalin and its derivatives are low-molecular-weight antioxidants, it was likely that they will penetrate the BBB [27]. AD-related therapeutic agents are required to penetrate the $\mathrm{BBB}$ and reach their target. Therefore, to estimate $\mathrm{BBB}$ penetration capacity, the lipophilicity, number of hydrogen bonds, polar surface area (PSA), molecular weight (MW), etc., of ramalin and its derivatives were examined (Table 1) [28]. Drugs acting on the central nervous system that were introduced between 1983 and 2002 had an average MW of approximately $310 \mathrm{Da}$, and a MW $<450 \mathrm{Da}$ has been suggested as a requirement for such drugs [28]. Given that ramalin and its derivatives are water-soluble 
low-molecular-weight compounds and that their lipophilicities and hydrophilicities balance out, their influence on AlogP, which indicates lipophilicity, was not significant. Additionally, given their PSA values $\left(90 \AA^{2}<\right.$ PSA $<140 \AA^{2}$ ), they are considered to be advantageous in terms of BBB penetration [28,29].

Table 1. Properties of potentially active molecules and DPPH $\mathrm{IC}_{50}(\mu \mathrm{M})^{1}$ values.

\begin{tabular}{ccccccc}
\hline Test Samples & PSA ${\left(\mathbf{A}^{2}\right)}^{2}$ & ALogP & HBA $^{2}$ & HBD $^{3}$ & MW & DPPH IC $_{\mathbf{5 0}}$ \\
\hline Ramalin & 128 & -2.5234 & 5 & 5 & 253.26 & 2.85 \\
RA-2Me & 104.45 & -1.7952 & 4 & 4 & 251.29 & 2.79 \\
RA-3Me & 104.45 & -1.7952 & 4 & 4 & 251.29 & 5.3 \\
RA-4Me & 104.45 & -1.309 & 4 & 4 & 251.29 & 3.91 \\
RA-25Me & 104.45 & -1.309 & 4 & 4 & 265.31 & 4.5 \\
RA-34Me & 104.45 & -2.0759 & 4 & 4 & 265.31 & 4.46 \\
RA-2F & 104.45 & -2.0759 & 4 & 4 & 255.25 & 4.42 \\
RA-4F & 104.45 & -1.8704 & 4 & 4 & 255.25 & 4.16 \\
RA-24F & 104.45 & -1.2539 & 4 & 4 & 273.24 & 5.32 \\
RA-PF & 104.45 & -0.9732 & 4 & 4 & 327.21 & 116 \\
\hline
\end{tabular}

${ }^{1}$ BHA DPPH $\mathrm{IC}_{50}=8.25 \mu \mathrm{M} .{ }^{2}$ HBA: hydrogen bond accepter. ${ }^{3}$ HBD: hydrogen bond donor.

\subsection{Antioxidant Effects of Ramalin and Its Derivatives}

The in vitro antioxidant effects of ramalin (free radical scavenging ability, $\mathrm{Fe}^{3+}$ reducing power, superoxide anion scavenging ability, and tyrosinase inhibitory effects) have been confirmed in a previous study [20]. A 2,2-diphenyl-1-picryl-hydrazyl-hydrate (DPPH) assay was performed to verify the antioxidant effects of the newly synthesized ramalin derivatives (Table 1). Based on the results obtained, ramalin derivatives showed a higher antioxidant efficiency than commercially available butylated hydroxyanisole (BHA). Among the derivatives tested, the antioxidant effect of RA-2Me was found to be the most similar to that of ramalin. Further, the antioxidant effect of RA-PF showed a relatively high $\mathrm{IC}_{50}$ value. However, additional experiments are needed to determine whether the antioxidant activity decreases in the absence of a phenyl proton.

\subsection{BACE-1 Inhibitory Activity of Ramalin and Its Derivatives}

Slight BACE-1 expression can lead to the accumulation of A $\beta$, which causes AD, and this can be fatal given that AD is a chronic disease. Therefore, BACE- 1 inhibition is a promising target for the suppression of AD. In this study, we used PanVera ${ }^{\circledR}$ 's BACE-1 fluorescence resonance energy transfer (FRET) assay kit (P2985, Madison, WI, USA) to confirm the BACE-1 inhibitory activity of ramalin and its derivatives [30]. The corresponding $\mathrm{IC}_{50}$ values of ramalin and its synthesized derivatives are shown in Table 2 . The standard positive control agent used was commercially available LY2811376. The experiments were each performed in triplicates for all of the compounds. Thus, it was observed that except for $\mathrm{RA}-24 \mathrm{~F}$, ramalin and all its other derivatives showed $\mathrm{IC}_{50}$ values at micromolar concentrations. Specifically, the BACE-1 inhibitory activity of ramalin was $17.66 \pm 2.74 \mu \mathrm{M}$, and among the derivatives RA-25Me showed the highest activity at $9.81 \pm 1.21 \mu \mathrm{M}$.

Table 2. In vitro inhibition of BACE-1 by ramalin and its derivatives.

\begin{tabular}{cc}
\hline Test Samples & ${\text { BACE-1 } \text { IC }_{\mathbf{5 0}}(\boldsymbol{\mu M})}^{\text {Ramalin }}$ \\
RA-2Me & $17.66 \pm 2.74$ \\
RA-3Me & $15.03 \pm 4.92$ \\
RA-4Me & $22.47 \pm 0.69$ \\
RA-25Me & $12.95 \pm 1.62$ \\
RA-34Me & $9.81 \pm 1.21$ \\
RA-2F & $13.09 \pm 1.52$ \\
RA-4F & $18.83 \pm 3.86$ \\
RA-24F & $20.12 \pm 4.78$ \\
RA-PF & ND \\
LY2811376 & $14.64 \pm 6.08$ \\
\hline
\end{tabular}

${ }^{1}$ RA-24F up to $50 \mu \mathrm{M}$ concentration. ${ }^{2}$ LY2811376 was used as a standard positive control agent. 


\subsection{Anti-Inflammatory Activity of Ramalin and Its Derivatives}

The importance of inflammation in the pathogenesis of $\mathrm{AD}$ has been recognized. It has also been confirmed that inflammation plays a role in AD pathology and exacerbates the disease [31]. Thus, we investigated the cytotoxicity of ramalin and its derivatives and measured their nitric oxide concentration to confirm their anti-inflammatory activity. Ramalin was found to be slightly cytotoxic at the maximum concentration (Figure 2). Conversely, its derivatives exerted no cytotoxic effects on these cells. Further, ramalin showed nitrogen oxide (NO) inhibitory activity in a concentration-dependent manner. Its derivatives, including RA-25Me, RA-34Me, RA-2F, RA-4F, RA-24F, and RA-PF, also showed concentration-dependent $\mathrm{NO}$ inhibition, whereas RA-2Me, RA-3Me, and RA-4Me exerted weak anti-inflammatory effects. Additionally, among these derivatives, RA-24F showed a stronger anti-inflammatory effect than ramalin, without cytotoxicity.
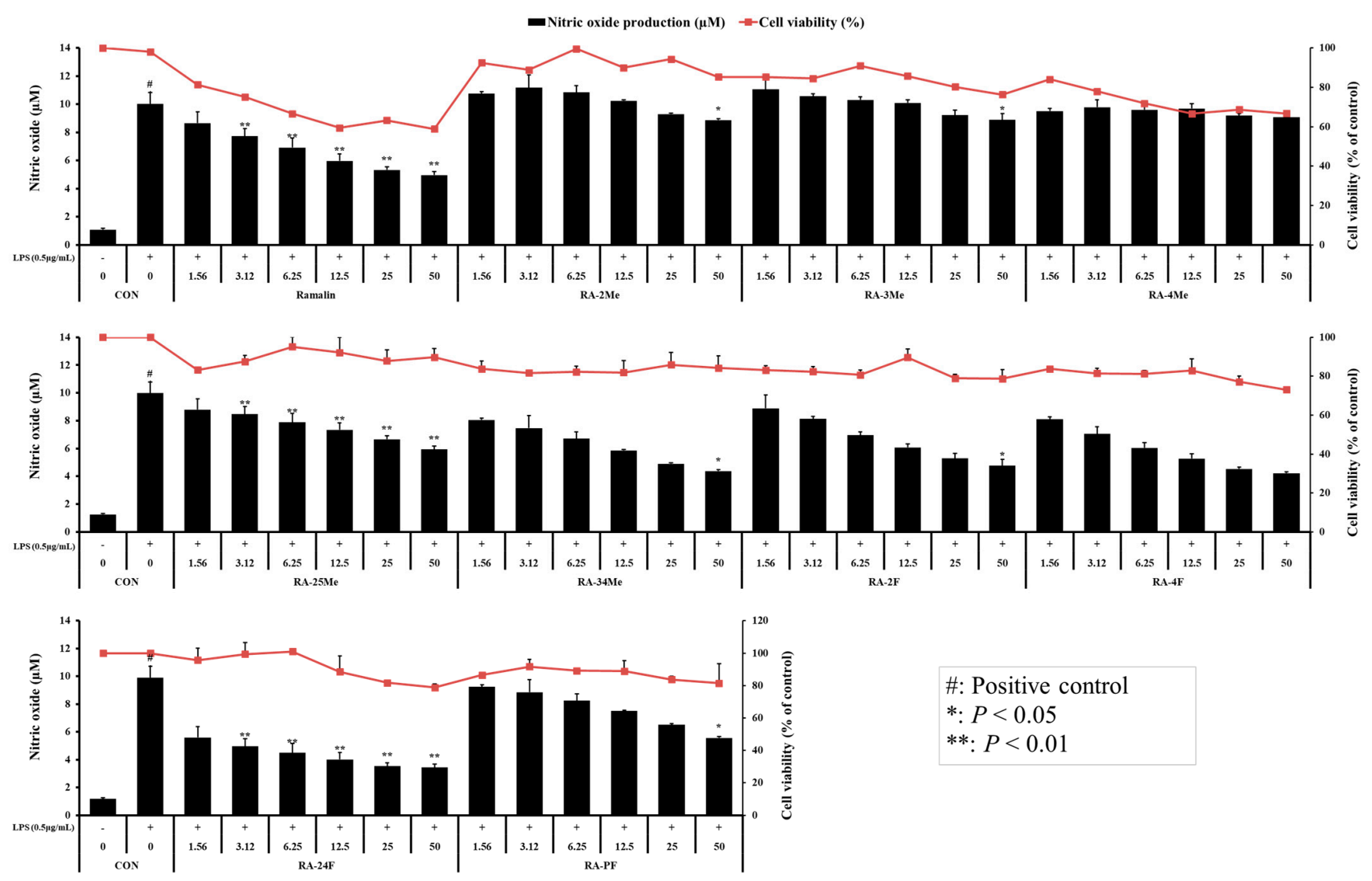

$$
\begin{aligned}
& \text { \#: Positive control } \\
& *: P<0.05 \\
& * *: P<0.01
\end{aligned}
$$

Figure 2. Anti-inflammatory activity and cell viability of ramalin and its derivatives.

\section{Discussion}

In this study, the antioxidant, BACE-1 inhibitory, and anti-inflammatory activities of ramalin and its derivatives were evaluated. Nine ramalin derivatives were synthesized with a relatively high yield $(62-79 \%)$ under conditions similar to those that were employed for ramalin synthesis. The synthesized derivatives, possessing methyl groups or a fluorine atom, exerted antioxidant effects similar to or better than that of ramalin. Further, the antioxidant effect of the derivatives differed depending on the position of the methyl group, and derivatives with $\mathrm{F}$ atoms showed relatively low antioxidant effects. Characteristically, RA-2Me showed a higher antioxidant effect than ramalin. Further, most of the synthesized derivatives, except for RA-2Me, RA-3Me, and RA-4Me, inhibited NO in a concentration-dependent manner, without cytotoxicity, and RA-24F in particular showed a higher anti-inflammatory effect than ramalin, without cytotoxicity. Additionally, except for RA-24F, ramalin and its derivatives exhibited BACE-1 inhibitory activity at micromolar 
concentrations. Among them, RA-25Me showed the highest BACE-1 inhibitory activity at $9.81 \pm 1.21 \mu \mathrm{M}$ concentration.

No clear electronic effects can be observed for aromatic systems consisting of electronwithdrawing or -donating groups. However, when RA-2Me and RA-2F were compared, RA2Me showed a superior antioxidant effect, while RA-2F showed good anti-inflammatory effects. Further, in terms of BACE-1 inhibitory activity, both the substances showed comparable results. Among the synthesized derivatives, RA-25Me and RA-34Me showed antioxidant, anti-inflammatory, and BACE-1 inhibitory activities similar to those of ramalin, but were better than ramalin in terms of cytotoxicity and stability. Conversely, RA-24F showed high anti-inflammatory activity; however, its BACE-1 inhibitory activity could not be confirmed.

Intensive efforts have been made to develop small-molecule BACE-1 inhibitors with sufficient inhibitory activity that can penetrate the BBB to reach the brain [32]. Even though therapeutic agents that target BACE-1 inhibition, which are big pharma favorites, can reduce $A \beta$ levels, no improvement in cognitive function in $A D$ patients has been observed [33], implying that early AD diagnosis and treatment are important. In recent studies, the development of small molecules with a multi-target approach centered on BACE-1, which considers the complexity of AD, has been reported [34]. Examples of such molecules include coumarin derivatives [35], which are inhibitors of BACE-1 and acetylcholinesterase (AchE), and curcumin derivatives [36,37], which are inhibitors of BACE- 1 and glycogen synthase kinase 3 beta (GSK-3 $\beta$ ). Therefore, compounds with multitarget activity are in the spotlight given that drugs that show only BACE-1 inhibitory activity present limitations. Further, memoquin, which exhibits inhibitory activities against BACE-1 and AChE as well as antioxidant effects, is a suitable example of a multi-target compound [38-40]. Spatial and episodic memory deficits in mice with scopolamine-induced amnesia have been resolved following memoquin treatment. Even though further confirmation is needed in this regard, antioxidant effects are necessary for substantial cognitive improvement as well as the clearance and suppression of $A \beta$ production in AD. Prior to the onset of $\mathrm{AD}$ through $\mathrm{A} \beta$ accumulation, ROS-induced oxidative damage accelerates $\mathrm{AD}$ induction. Further, ROS cause oxidative damage to the nucleic acids, lipids, and proteins that are associated with $\mathrm{AD}$ induction, and these damaged substances have been identified in the brains of patients with AD in the early stages [41]. Reportedly, oxidative damage causes neuroinflammation and mediates BACE- 1 activity [42,43], and A $\beta$ produced by BACE-1 can, in turn, lead to ROS production, which further exacerbates the symptoms of $\mathrm{AD}[8,44,45]$. Therefore, based on its various physiological activities, ramalin, a strong antioxidant, has considerable potential as a multi-target therapeutic agent for AD. However, further studies on its additional AD-inducer-related activities as well as those of its derivatives are needed. Therefore, the synthesis of derivatives with improved activity should be continued based on the results here presented.

\section{Materials and Methods}

\subsection{General Experimental Information}

All the solvent and reagents were obtained from the commercial suppliers Merck (Darmstadt, Germany) or TCI (Tokyo, Japan), and used without further purification. All glassware was thoroughly dried in a drying oven $\left(60^{\circ} \mathrm{C}\right)$ or flame and cooled down under a steam of dry argon just prior to use. A filter was obtained from the commercial supplier GE healthcare (GF/F, $0.7 \mu \mathrm{m}$, Whatman, UK). All reactions were carried out under an inert atmosphere of argon. Solvents and liquid reagents were transferred using a syringe. Organic extracts were dried over a drying agent, $\mathrm{Na}_{2} \mathrm{SO}_{4}$ and concentrated under reduced pressure with the aid of a rotary evaporator (Eyela, Tokyo, Japan). Residual solvents were removed under a high vacuum (Vacuubrand RZ 2.5, Wertheim, Germany, $1 \times 10^{-2} \mathrm{mbar}$ ). Accurate mass spectra were obtained with an AB Sciex Triple TOF 4600 (Framingham, MA, USA) instrument with the interface in direct injection mode. The IR spectra were measured using a Nicolet 6700 (Thermo Nicolet, Madison, WI, USA). NMR data were collected on 
a Jeol JNM ECP-400 spectrometer (Jeol Ltd., Tokyo, Japan) with a mixture of $\mathrm{D}_{2} \mathrm{O}$ (with $0.01 \mathrm{mg} / \mathrm{mL}$ of DSS)-acetone- $d_{6}(6: 1 v / v)$ or DMSO- $d_{6}$ (dimethyl sulfoxide- $\left.d_{6}\right)$ as solvents and the internal reference or the residual solvent signals for referencing $\left(\mathrm{D}_{2} \mathrm{O}\right.$ (with DSS)acetone- $\left.d_{6}: d \mathrm{H} 0.00 / d \mathrm{C} 29.8, \mathrm{DMSO}-d_{6}: d \mathrm{H} 2.50 / d \mathrm{C} 39.5\right)$. Peak splitting patterns were abbreviated as $\mathrm{m}$ (multiplet), s (singlet), d (doublet), $\mathrm{t}$ (triplet), dd (doublet of doublets), and $\mathrm{td}$ (triplet of doublets), respectively. A microplate reader (Thermo Scientific Inc., San Diego, CA, USA) and multimode plate reader (Multistkan ${ }^{\mathrm{TM}}$ GO, Thermo Scientific, Waltham, MA, USA) were used for absorbance analysis.

\subsection{Synthesis and Characterization \\ 4.2.1. General Method for the Synthesis of p-Glu-Hyd Analogues}

A $250 \mathrm{~mL}$ round-bottom flask equipped with a magnetic stir bar was charged with 1-Benzyl-N-Cbz-L-glutamic acid $(2.0 \mathrm{~g}, 5.39 \mathrm{mmol})$ in a DCM $(50 \mathrm{~mL})$ solvent. The reaction mixture was cooled to $-5^{\circ} \mathrm{C}$ and TEA $(1.2 \mathrm{eq}, 6.47 \mathrm{mmol}, 902 \mu \mathrm{L})$ was added slowly. After $10 \mathrm{~min}, \mathrm{ECF}(1.2 \mathrm{eq}, 6.47 \mathrm{mmol}, 615 \mu \mathrm{L})$ was added dropwise to the mixture over $1 \mathrm{~h}$. The reaction mixture was stirred for $4 \mathrm{~h}$ at $-5{ }^{\circ} \mathrm{C}$. Another $100 \mathrm{~mL}$ pear flask was prepared and charged with phenyl hydrazine $\mathrm{HCl}$ salt (1.2 eq, $6.47 \mathrm{mmol})$ and TEA (1.2 eq, $6.47 \mathrm{mmol}$, $902 \mu \mathrm{L})$, and then slowly added to the main reaction flask for $1 \mathrm{~h}$ at $-5{ }^{\circ} \mathrm{C}$. When the hydrazine addition was finished, the reaction mixture was warmed to room temperature and stirred for $16 \mathrm{~h}$. After completion of the reaction, the organic layer was washed in the order of distilled water, $1 \mathrm{~N} \mathrm{HCl}, 0.5 \mathrm{~N} \mathrm{NaHCO}_{3}$, and distilled water to separate the layers, and the organic layer was collected. The organic phase was dried over $\mathrm{Na}_{2} \mathrm{SO}_{4}$ and concentrated in a rotary evaporator. Purification was achieved by recrystallization from ethyl acetate/n-hexane (1:5).

\subsubsection{General Method for the Synthesis of Ramalin Derivatives}

A $500 \mathrm{~mL}$ round-bottom flask equipped with a magnetic stir bar was charged with an appropriate p-Glu-Hyd analogue $(4.5 \mathrm{mmol})$ and palladium on carbon $(10 \mathrm{wt} \%)$ in $\mathrm{MeOH}$ $200 \mathrm{~mL}$. The mixture was stirred under a hydrogen atmosphere (1 atm, hydrogen balloon) for $16 \mathrm{~h}$. Upon completion, the reaction mixture was filtered through glass microfiber filter paper $(0.7 \mu \mathrm{m})$. The filtrate was concentrated in a rotary evaporator. Purification was achieved by recrystallization from $\mathrm{MeOH}$ /ethyl acetate (1:5). Detailed information are presented in the Supplementary Materials.

$\mathrm{N}^{5}$-(o-Tolylamino)-L-glutamine (RA-2Me). From Benzyl-N-Cbz-L-glutamic acid; 0.94 g, $70 \%$, white solid; IR $\left(v \mathrm{~cm}^{-1}, \mathrm{KBr}\right): 3273,3030,1653,1584,1521 .{ }^{1} \mathrm{H} \mathrm{NMR}(400 \mathrm{MHz}$, $\mathrm{D}_{2} \mathrm{O} /$ Acetone- $\left.d_{6}(6 / 1)\right): \delta 7.17(\mathrm{~m}, 2 \mathrm{H}, \mathrm{PhH}), 6.90(\mathrm{td}, J=7.6,1.2,1 \mathrm{H}, \mathrm{PhH}), 6.84(\mathrm{dd}$, $J=8.0,0.8,1 \mathrm{H}, \mathrm{PhH}), 3.81(\mathrm{t}, J=6.0,1 \mathrm{H}, \mathrm{H}-2), 2.56(\mathrm{~m}, 2 \mathrm{H}, \mathrm{H}-4), 2.22\left(\mathrm{~s}, 3 \mathrm{H}, \mathrm{CH}_{3}\right), 2.21(\mathrm{~m}$, $2 \mathrm{H}, \mathrm{H}-3) ;{ }^{13} \mathrm{C}$ NMR (100 MHz D $2 \mathrm{O} /$ Acetone- $\left._{6}(6 / 1)\right): \delta 174.8,174.0,145.2,131.0,127.4$, $123.9,121.3,112.2,54.5,29.9,26.5,16.5$; HRESIMS $m / z 252.1352[\mathrm{M}+\mathrm{H}]^{+}$(calculated for $^{2}$ $\left.\mathrm{C}_{12} \mathrm{H}_{18} \mathrm{~N}_{3} \mathrm{O}_{3}, 252.1348\right)$.

$\mathrm{N}^{5}$-(m-Tolylamino)-L-glutamine (RA-3Me). From Benzyl-N-Cbz-L-glutamic acid; $0.97 \mathrm{~g}$, $72 \%$, white solid, IR ( $\left.v \mathrm{~cm}^{-1}, \mathrm{KBr}\right): 3265,3037,1649,1609,1593,1513 .{ }^{1} \mathrm{H} \mathrm{NMR}(400 \mathrm{MHz}$, $\mathrm{D}_{2} \mathrm{O} /$ Acetone- $\left.d_{6}(6 / 1)\right): \delta 7.19(\mathrm{t}, J=7.6,1 \mathrm{H}, \mathrm{PhH}), 6.79(\mathrm{~d}, J=7.6,1 \mathrm{H}, \mathrm{PhH}), 6.72(\mathrm{~s}, 1 \mathrm{H}$, $\mathrm{PhH}), 6.69(\mathrm{~d}, J=8.0,1 \mathrm{H}, \mathrm{PhH}), 3.80(\mathrm{t}, J=6.4,1 \mathrm{H}, \mathrm{H}-2), 2.54(\mathrm{~m}, 2 \mathrm{H}, \mathrm{H}-4), 2.27\left(\mathrm{~s}, 3 \mathrm{H}, \mathrm{CH}_{3}\right)$, 2.20 (m, 2H, H-3); ${ }^{13} \mathrm{C}$ NMR (100 MHz D $2 \mathrm{O} /$ Acetone- $\left.d_{6}(6 / 1)\right): \delta 175.0,174.1,147.7,140.3$, $129.8,122.3,114.2,110.9,54.5,29.9,26.5,20.9 ;$ HRESIMS $m / z 252.1367[\mathrm{M}+\mathrm{H}]^{+}$(calculated $^{2}$ for $\mathrm{C}_{12} \mathrm{H}_{18} \mathrm{~N}_{3} \mathrm{O}_{3}, 252.1348$ ).

$\mathrm{N}^{5}$-(p-Tolylamino)-L-glutamine (RA-4Me). From Benzyl-N-Cbz-L-glutamic acid; $0.90 \mathrm{~g}$, $67 \%$, white solid, IR ( $\left.v \mathrm{~cm}^{-1}, \mathrm{KBr}\right): 3238,3025,1651,1614,1512 .{ }^{1} \mathrm{H} \mathrm{NMR}(400 \mathrm{MHz}$, $\mathrm{D}_{2} \mathrm{O} /$ Acetone- $\left.d_{6}(6 / 1)\right): \delta 7.15(\mathrm{~d}, J=8.4,2 \mathrm{H}, \mathrm{PhH}), 6.82(\mathrm{~d}, J=8.0,2 \mathrm{H}, \mathrm{PhH}), 3.79(\mathrm{t}$, $J=6.4,1 \mathrm{H}, \mathrm{H}-2), 2.52$ (m, 2H, H-4), $2.25\left(\mathrm{~s}, 3 \mathrm{H}, \mathrm{CH}_{3}\right), 2.18(\mathrm{~m}, 2 \mathrm{H}, \mathrm{H}-3) ;{ }^{13} \mathrm{C} \mathrm{NMR}(100$ $\mathrm{MHz} \mathrm{D}_{2} \mathrm{O} /$ Acetone- $\left.d_{6}(6 / 1)\right): \delta 174.9,174.1,145.1,131.5,130.2,114.1,54.5,29.9,26.5,19.9$; HRESIMS $m / z 252.1367[\mathrm{M}+\mathrm{H}]^{+}$(calculated for $\mathrm{C}_{12} \mathrm{H}_{18} \mathrm{~N}_{3} \mathrm{O}_{3}, 252.1348$ ). 
$\mathrm{N}^{5}$-((2,5-Dimethylphenyl)amino)-L-glutamine (RA-25Me). From Benzyl-N-Cbz-L-glutamic acid; $1.12 \mathrm{~g}$, 78\%, white solid, IR ( $\left(\mathrm{cm}^{-1}, \mathrm{KBr}\right): 3257,2929,1624,1509 .{ }^{1} \mathrm{H}$ NMR $(400 \mathrm{MHz}$, $\mathrm{D}_{2} \mathrm{O} /$ Acetone- $\left.d_{6}(6 / 1)\right): \delta 6.89(\mathrm{~d}, J=7.6,1 \mathrm{H}, \mathrm{PhH}), 6.57(\mathrm{~d}, J=7.6,1 \mathrm{H}, \mathrm{PhH}), 6.52(\mathrm{~s}, 1 \mathrm{H}$, $\mathrm{PhH}), 3.67(\mathrm{t}, J=6.4,1 \mathrm{H}, \mathrm{H}-2), 2.43(\mathrm{~m}, 2 \mathrm{H}, \mathrm{H}-4), 2.10\left(\mathrm{~s}, 3 \mathrm{H}, \mathrm{CH}_{3}\right), 2.06(\mathrm{~m}, 2 \mathrm{H}, \mathrm{H}-3), 2.03$ $\left(\mathrm{s}, 3 \mathrm{H}, \mathrm{CH}_{3}\right) ;{ }^{13} \mathrm{C}$ NMR $\left(100 \mathrm{MHz} \mathrm{D}_{2} \mathrm{O} /\right.$ Acetone- $\left.d_{6}(6 / 1)\right): \delta 174.4,173.7,144.9,137.1,130.7$, $121.5,120.4,112.5,54.2,29.6,26.3,20.4,15.8$; HRESIMS $m / z 266.1507[\mathrm{M}+\mathrm{H}]^{+}$(calculated for $\left.\mathrm{C}_{13} \mathrm{H}_{20} \mathrm{~N}_{3} \mathrm{O}_{3}, 266.1505\right)$.

$\mathrm{N}^{5}$-((3,4-Dimethylphenyl)amino)-L-glutamine (RA-34Me). From Benzyl- $N$-Cbz-L-glutamic acid; $1.01 \mathrm{~g}$, 70\%, white solid, IR ( $\left.v \mathrm{~cm}^{-1}, \mathrm{KBr}\right): 3256,2919,1652,1615,1506 .{ }^{1} \mathrm{H}$ NMR $(400$ MHz, $\mathrm{D}_{2} \mathrm{O} /$ Acetone- $\left.d_{6}(6 / 1)\right): \delta 7.06(\mathrm{~d}, J=8.0,1 \mathrm{H}, \mathrm{PhH}), 6.71(\mathrm{~d}, J=2.4,1 \mathrm{H}, \mathrm{PhH}), 6.64$ $(\mathrm{dd}, J=8.0,2.4,1 \mathrm{H}, \mathrm{PhH}), 3.80(\mathrm{t}, J=6.4,1 \mathrm{H}, \mathrm{H}-2), 2.53(\mathrm{~m}, 2 \mathrm{H}, \mathrm{H}-4), 2.20(\mathrm{~m}, 2 \mathrm{H}, \mathrm{H}-3), 2.19$ $\left(\mathrm{s}, 3 \mathrm{H}, \mathrm{CH}_{3}\right) .2 .15\left(\mathrm{~s}, 3 \mathrm{H}, \mathrm{CH}_{3}\right) ;{ }^{13} \mathrm{C}$ NMR $\left(100 \mathrm{MHz} \mathrm{D}_{2} \mathrm{O} /\right.$ Acetone- $\left.d_{6}(6 / 1)\right): \delta$ 174.7, 173.9 , $145.7,138.3,130.6,129.9,115.3,111.4,54.5,29.9,26.6,19.4,18.3$; HRESIMS $m / z 266.1508$ [M + $\mathrm{H}]^{+}$(calculated for $\mathrm{C}_{13} \mathrm{H}_{20} \mathrm{~N}_{3} \mathrm{O}_{3}, 266.1505$ ).

$\mathrm{N}^{5}$-((2-Fluorophenyl)amino)-L-glutamine (RA-2F). From Benzyl-N-Cbz-L-glutamic acid; $0.85 \mathrm{~g}, 62 \%$, white solid, IR $\left(v \mathrm{~cm}^{-1}, \mathrm{KBr}\right): 3249,3046,1659,1619,1501 .{ }^{1} \mathrm{H}$ NMR $(400 \mathrm{MHz}$, $\mathrm{D}_{2} \mathrm{O} /$ Acetone- $\left.d_{6}(6 / 1)\right): \delta 7.15-7.08(\mathrm{~m}, 2 \mathrm{H}, \mathrm{PhH}), 6.97-6.90(\mathrm{~m}, 2 \mathrm{H}, \mathrm{PhH}), 3.80(\mathrm{t}, J=6.0$, $1 \mathrm{H}, \mathrm{H}-2), 2.55$ (m, 2H, H-4), 2.20 (m, 2H, H-3); ${ }^{13} \mathrm{C}$ NMR (100 MHz D $2 \mathrm{O} /$ Acetone- $\left.d_{6}(6 / 1)\right)$ : $\delta$ 175.0, 174.0, $151.5\left(\mathrm{~d},{ }^{1} J_{\mathrm{CF}}=238.4, \mathrm{CF}\right), 135.3\left(\mathrm{~d},{ }^{2} J_{\mathrm{CF}}=10.9\right), 125.2\left(\mathrm{~d},{ }^{4} J_{\mathrm{CF}}=3.5\right), 121.7(\mathrm{~d}$, $\left.{ }^{3} J_{\mathrm{CF}}=6.9\right), 115.7\left(\mathrm{~d},{ }^{2} J_{\mathrm{CF}}=17.9\right), 114.9\left(\mathrm{~d},{ }^{3} J_{\mathrm{CF}}=2.5\right), 54.5,29.9,26.5 ;$ HRESIMS $m / z 256.1059$ $[\mathrm{M}+\mathrm{H}]^{+}$(calculated for $\mathrm{C}_{11} \mathrm{H}_{15} \mathrm{FN}_{3} \mathrm{O}_{3}, 256.1097$ ).

$\mathrm{N}^{5}$-((4-Fluorophenyl)amino)-L-glutamine (RA-4F). From Benzyl-N-Cbz-L-glutamic acid; $0.90 \mathrm{~g}, 65 \%$, white solid, IR $\left(v \mathrm{~cm}^{-1}, \mathrm{KBr}\right): 3266,3024,1649,1609,1508 .{ }^{1} \mathrm{H}$ NMR $(400 \mathrm{MHz}$, $\mathrm{D}_{2} \mathrm{O} /$ Acetone- $\left.d_{6}(6 / 1)\right): \delta$ 7.09-7.04 (m, $\left.2 \mathrm{H}, \mathrm{PhH}\right), 6.92-6.88(\mathrm{~m}, 2 \mathrm{H}, \mathrm{PhH}), 3.82(\mathrm{td}, J=6.0$, $1.2,1 \mathrm{H}, \mathrm{H}-2), 2.54(\mathrm{~m}, 2 \mathrm{H}, \mathrm{H}-4), 2.21(\mathrm{~m}, 2 \mathrm{H}, \mathrm{H}-3) ;{ }^{13} \mathrm{C}$ NMR $\left(100 \mathrm{MHz} \mathrm{D}_{2} \mathrm{O} /\right.$ Acetone- $d_{6}$ (6/1)): $\delta 175.0,174.1,158.0\left(\mathrm{~d},{ }^{1} J_{\mathrm{CF}}=234.8, \mathrm{CF}\right), 143.7\left(\mathrm{~d},{ }^{4} J_{\mathrm{CF}}=2.1\right), 116.1\left(\mathrm{~d},{ }^{2} J_{\mathrm{CF}}=22.8\right)$, $115.2\left(\mathrm{~d},{ }^{3} J_{\mathrm{CF}}=8.0\right), 54.4,29.8,26.4$; HRESIMS $\mathrm{m} / \mathrm{z} 256.1106[\mathrm{M}+\mathrm{H}]^{+}$(calculated for $\left.\mathrm{C}_{11} \mathrm{H}_{15} \mathrm{FN}_{3} \mathrm{O}_{3}, 256.1097\right)$.

$\mathrm{N}^{5}$-((2,4-Difluorophenyl)amino)-L-glutamine (RA-24F). From Benzyl-N-Cbz-L-glutamic acid; $1.10 \mathrm{~g}$, 75\%, white solid, IR $\left(v \mathrm{~cm}^{-1}, \mathrm{KBr}\right): 3271,3043,1655,1609,1508 .{ }^{1} \mathrm{H}$ NMR $\left(400 \mathrm{MHz}, \mathrm{D}_{2} \mathrm{O} /\right.$ Acetone- $\left.d_{6}(6 / 1)\right): \delta 6.99(\mathrm{~m}, 1 \mathrm{H}, \mathrm{PhH}), 6.94(\mathrm{~m}, 1 \mathrm{H}, \mathrm{PhH}), 6.89(\mathrm{~m}, 1 \mathrm{H}$, $\mathrm{PhH}), 3.79(\mathrm{t}, J=6.4,1 \mathrm{H}, \mathrm{H}-2), 2.52(\mathrm{~m}, 2 \mathrm{H}, \mathrm{H}-4), 2.18(\mathrm{~m}, 2 \mathrm{H}, \mathrm{H}-3) ;{ }^{13} \mathrm{C} \mathrm{NMR}(100 \mathrm{MHz}$ $\mathrm{D}_{2} \mathrm{O} /$ Acetone- $\left.d_{6}(6 / 1)\right): \delta 175.1,174.1,157.1\left(\mathrm{dd},{ }^{4} J_{\mathrm{CF}}=3.3,{ }^{1} J_{\mathrm{CF}}=237.9, \mathrm{CF}\right), 151.2(\mathrm{dd}$, $\left.{ }^{3} J_{\mathrm{CF}}=12.2,{ }^{1} J_{\mathrm{CF}}=241.9, \mathrm{CF}\right), 131.8\left(\mathrm{dd},{ }^{4} J_{\mathrm{CF}}=3.3,{ }^{2} J_{\mathrm{CF}}=11.1\right), 115.8\left(\mathrm{dd},{ }^{3} J_{\mathrm{CF}}=3.9\right.$, $\left.{ }^{3} J_{\mathrm{CF}}=9.4\right), 111.4\left(\mathrm{dd},{ }^{4} J_{\mathrm{CF}}=3.7,{ }^{2} J_{\mathrm{CF}}=22.1\right), 104.3\left(\mathrm{dd},{ }^{2} J_{\mathrm{CF}}=22.3,{ }^{2} J_{\mathrm{CF}}=26.9\right), 54.5,29.8$, 26.4; HRESIMS $m / z 274.0963[\mathrm{M}+\mathrm{H}]^{+}$(calculated for $\mathrm{C}_{11} \mathrm{H}_{14} \mathrm{~F}_{2} \mathrm{~N}_{3} \mathrm{O}_{3}$, 274.1003).

$\mathrm{N}^{5}$-((Perfluorophenyl)amino)-L-glutamine (RA-PF). From Benzyl-N-Cbz-L-glutamic acid; $1.39 \mathrm{~g}, 79 \%$, white solid, IR $\left(v \mathrm{~cm}^{-1}, \mathrm{KBr}\right): 3278,3022,1666,1628,1523 .{ }^{1} \mathrm{H}$ NMR $(400$ MHz, DMSO- $\left.d_{6}\right): \delta 3.20(\mathrm{t}, J=6.4,1 \mathrm{H}, \mathrm{H}-2), 2.27(\mathrm{~m}, 2 \mathrm{H}, \mathrm{H}-4), 1.85(\mathrm{~m}, 2 \mathrm{H}, \mathrm{H}-3) ;{ }^{13} \mathrm{C}$ NMR (100 MHz DMSO-d $\left.d_{6}\right): \delta 172.0,169.5,137.3\left(\mathrm{br} \mathrm{d},{ }^{1} J_{\mathrm{CF}}=246.0,4 \mathrm{C}\right), 133.5$ (br d, $\left.{ }^{1} J_{\mathrm{CF}}=250.5,1 \mathrm{C}\right), 124.8(\mathrm{~m}, 1 \mathrm{C}), 53.5,29.6,26.9$; HRESIMS $\mathrm{m} / z 328.0725[\mathrm{M}+\mathrm{H}]^{+}$(calculated for $\left.\mathrm{C}_{11} \mathrm{H}_{14} \mathrm{~F}_{2} \mathrm{~N}_{3} \mathrm{O}_{3}, 328.0721\right)$.

\subsection{DPPH Assay (In Vitro)}

According to the Blois, M.S. et al. method, the DPPH radical scavenging activity of ramalin and its derivatives was assessed [46]. Briefly, $150 \mu \mathrm{L}$ of ramalin, its derivatives, and BHA at a 10, 5, 2.5, and $1 \mu \mathrm{M}$ concentration solution in $\mathrm{MeOH}$ was mixed with $50 \mu \mathrm{L}$ of $0.1 \mathrm{mM}$ DPPH in $\mathrm{MeOH}$, and then placed in the dark for $30 \mathrm{~min}$ at room temperature. Then, the mixture was determined at $540 \mathrm{~nm}$. 


\subsection{Anti-Inflamation Activity Assay}

\subsubsection{Cell Culture}

The macrophage-like murine cell line RAW 264.7 (KCLB number 40071; Korean Cell Line Bank, Seoul, Korea) was cultured in Dulbecco's Modified Eagle Medium (DMEM, Sigma-Aldrich, St. Louis, MO, USA) supplemented with 10\% heat-inactivated fetal bovine serum (FBS, Invitrogen, Burlington, ON, Canada) and 1\% (w/v) antibiotic-antimycotic solution (Invitrogen, Grand Island, NY, USA) at $5 \% \mathrm{CO}_{2}$ and $37^{\circ} \mathrm{C}$.

\subsubsection{Cytotoxicity Assay}

Cell cytotoxicity was determined by an MTT (3-(4,5)-dimethylthiazol-2-yl-2,5-diphenyltetrazoli bromide, Amresco, Solon, OH, USA) colorimetric assay. RAW 264.7 cells were seeded at a density of $2 \times 105$ cells $/ \mathrm{mL}$ in 96 -well plates and incubated in the presence of various concentrations of ramalin and its derivatives for $24 \mathrm{~h}$. After incubation with test substances, MTT solutions ( $5 \mu \mathrm{L}$ of a $5 \mathrm{mg} / \mathrm{mL}$ concentration in PBS) were added to the wells and incubated for $4 \mathrm{~h}$ at $37^{\circ} \mathrm{C}$. Then, treated with $100 \mu \mathrm{L}$ of fresh DMSO to dissolve the crystals for $10 \mathrm{~min}$, the cells were detected under a microplate reader (Thermo Scientific Inc., San Diego, CA, USA) to measure the absorbance at $570 \mathrm{~nm}$. Relative cell viability was calculated by comparing the absorbance of the untreated control group. All experiments were performed in triplicate.

\subsubsection{Determination of Nitric Oxide Production}

Nitrite accumulation was used as an indicator of NO production in the medium, and the nitrite level was determined by assaying the culture supernatants for nitrite using the Griess reagent (1\% sulfanilamide, $0.1 \% N$-(1-naphathyl)-ethylenediamine dihydrochloride, and $5 \%$ phosphoric acid). In order to measure the amount of nitrite, $1 \times 106$ cells $/ \mathrm{mL}$ were seeded onto 96-well plates and then treated with the indicated concentrations of ramalin and its derivatives at $37^{\circ} \mathrm{C}$ for $1 \mathrm{~h}$, followed by stimulation with $0.5 \mu \mathrm{g} / \mathrm{mL}$ of lipopolysaccaride (LPS, $0.5 \mu \mathrm{g} / \mathrm{mL}$, Sigma-Aldrich, CA, USA) for $24 \mathrm{~h}$ in a final volume of $200 \mu \mathrm{L}$. Then, $100 \mu \mathrm{L}$ of cell culture supernatants were mixed with $100 \mu \mathrm{L}$ of Griess reagent in a 96-well plate. Sodium nitrite was used to generate a standard curve and the concentration of nitrite was then measured by the absorbance at $540 \mathrm{~nm}$ using a microplate reader. All determinations were performed in triplicate.

\section{5. $\beta$-Secretase (BACE-1) Inhibition Assay}

A BACE-1 inhibition assay was conducted using a $\beta$-Secretase FRET kit (BACE-1, Thermo Fisher Sientific, San Diego, CA, USA) according to manufacturer instructions. The assay was carried out according to the manufacturer's protocol as described earlier. A stock of ramalin and its derivatives in deionized distilled water (DDW) was prepared $(20 \mathrm{mM})$. The sample was diluted further in assay buffer (final concentrations of 50, 25, 12.5, 6.25, $3.12,1.56,0.78,0.39,0.2$, and $0.1 \mu \mathrm{M}$ in each well) and black 96-well microplates were mixed with $10 \mu \mathrm{L}$ of BACE- 1 substrate. Then, $10 \mu \mathrm{L}$ of $3 \times$ BACE- 1 enzyme was added to each well to start the reaction. Plates were incubated at room temperature in the dark for $60 \mathrm{~min}$. After incubation, $10 \mu \mathrm{L}$ of $2.5 \mathrm{mM}$ sodium acetate was added to each well to stop the reaction. Finally, multiwell spectrofluorometer instruments were used for a multimode plate reader (Multistkan ${ }^{\mathrm{TM}}$ GO, Thermo Scientific, Waltham, MA, USA) at an excitation wavelength of $545 \mathrm{~nm}$ and an emission wavelength of $585 \mathrm{~nm}$. The half-maximal inhibitory concentration $\left(\mathrm{IC}_{50}\right)$ was calculated by plotting the obtained relative fluorescence unit per hour $(\mathrm{RFU} / \mathrm{h})$ against the logarithmic of the inhibitor concentration. All determinations were performed in triplicate.

\section{Conclusions}

$\mathrm{AD}$ has a complex pathophysiology that includes pathological protein aggregation, neurotransmission disorders, increased oxidative stress, and microglia-mediated neuroinflammation. Therapeutic agents targeting only one of the molecular targets associated with 
AD have been reported. For example, therapeutic agents with high BACE-1 inhibitory activity can successfully suppress and eliminate $A \beta$ production, but cannot restore cognitive function. Therefore, while developing therapeutic agents for $A D$, it is important to focus on multi-target drugs rather than single-target drugs. Ramalin, which possesses antioxidant, BACE-1 inhibitory, and anti-inflammatory activities, could serve as a promising therapeutic agent with multiple activities that could address the complex nature of AD. However, its application is limited owing to its low stability in aqueous environments and high-concentration cytotoxicity. RA-25Me and RA-34Me exhibited activity similar to that of ramalin, and highlighted the possibility of ameliorating these disadvantages. Therefore, the improvement of the physical properties and activities of ramalin via the synthesis of additional derivatives can lead to its application in $\mathrm{AD}$ treatment and prevention in future.

Supplementary Materials: The following are available online.

Author Contributions: Conceptualization, T.K.K., J.-M.H. and J.H.Y.; methodology, T.K.K., J.-M.H. and K.H.K.; software, J.-M.H., I.-C.K. and J.H.Y.; validation, T.K.K., J.-M.H., S.J.H., H.O. and J.H.Y.; formal analysis, T.K.K., J.-M.H., K.H.K. and H.O.; investigation, T.K.K., J.-M.H. and J.H.Y.; resources, S.J.H., I.-C.K. and J.H.Y.; data curation, T.K.K. and J.-M.H.; writing-original draft preparation, T.K.K. and J.-M.H.; writing-review and editing, J.H.Y.; visualization, T.K.K. and J.-M.H.; supervision, J.H.Y.; project administration, J.H.Y. All authors have read and agreed to the published version of the manuscript.

Funding: This research was funded by the Korea Polar Research Institute, KOPRI, grant number PM21010.

Institutional Review Board Statement: Not applicable.

Informed Consent Statement: Not applicable.

Data Availability Statement: The data presented in this study are available in this article.

Conflicts of Interest: The authors declare no conflict of interest.

\section{References}

1. Nichols, E.; Szoeke; Cassandra, E.; Volset, S.E.; Abbasi, N.; Abd-Allah, F.; Abdela, J.; Aichour, M.T.E.; Akinyiemi, R.O.; Murray, C.J.; et al. Global, regional, and national burden of Alzheimer's disease and other dementias, 1990-2016: A systematic analysis for the Global Burden of Disease Study 2016. Lancet Neurol. 2019, 18, 88-106. [CrossRef]

2. Etters, L.; Goodall, D.; Harrison, B.E. Caregiver burden among dementia patient caregivers: A review of the literature. J. Am. Acad. Nurse Pr. 2008, 20, 423-428. [CrossRef] [PubMed]

3. Dumurgier, J.; Sabia, S. Life expectancy in dementia subtypes: Exploring a leading cause of mortality. Lancet Health Longev. 2021. [CrossRef]

4. Mucke, L. Alzheimer's disease. Nature 2019, 461, 895-897. [CrossRef]

5. Vassar, R. Bace 1. J. Mol. Neurosci. 2004, 23, 105-113. [CrossRef]

6. Roberson, E.D.; Mucke, L. 100 years and counting: Prospects for defeating Alzheimer's disease. Science 2006, 314, 781-784. [CrossRef] [PubMed]

7. Oakley, H.; Cole, S.L.; Logan, S.; Maus, E.; Shao, P.; Craft, J.; Guillozet-Bongaarts, A.; Ohno, M.; Disterhoft, J.; Vassar, R. Intraneuronal $\beta$-amyloid aggregates, neuro-degeneration, and neuron loss in transgenic mice with five familial Alzheimer's disease mutations: Potential factors in amyloid plaque formation. J. Neurosci. 2006, 26, 10129-10140. [CrossRef]

8. Tamagno, E.; Bardini, P.; Guglielmotto, M.; Danni, O.; Tabaton, M. The various aggregation states of $\beta$-amyloid 1-42 mediate different effects on oxidative stress, neurodegeneration, and BACE-1 expression. Free Radic. Biol. Med. 2006, 41, 202-212. [CrossRef]

9. Philippens, I.H.; Ormel, P.R.; Baarends, G.; Johansson, M.; Remarque, E.J.; Doverskog, M. Acceleration of amyloidosis by inflammation in the amyloid-beta marmoset monkey model of Alzheimer's disease. J. Alzheimer's Dis. 2017, 55, 101-113. [CrossRef] [PubMed]

10. McGeer, E.G.; McGeer, P.L. The importance of inflammatory mechanisms in alzheimer disease. Exp. Gerontol. 1998, 33, 371-378. [CrossRef]

11. Roßner, S.; Sastre, M.; Bourne, K.; Lichtenthaler, S.F. Transcriptional and translational regulation of BACE1 expres-sionImplications for Alzheimer's disease. Prog. Neurobiol. 2006, 79, 95-111. [CrossRef] [PubMed]

12. Smith, M.A.; Rottkamp, C.A.; Nunomura, A.; Raina, A.K.; Perry, G. Oxidative stress in Alzheimer's disease. Biochim. Biophys. Acta Mol. Basis Dis. 2000, 1502, 139-144. [CrossRef] 
13. Dumont, M.; Beal, M.F. Neuroprotective strategies involving ROS in Alzheimer disease. Free. Radic. Biol. Med. 2011, 51, $1014-1026$. [CrossRef]

14. Wang, X.; Wang, W.; Li, L.; Perry, G.; Lee, H.G.; Zhu, X. Oxidative stress and mitochondrial dysfunction in Alzheimer's disease. Biochim. Biophys. Acta Mol. Basis Dis. 2014, 1842, 1240-1247. [CrossRef]

15. Takuma, K.; Yan, S.S.; Stern, D.M.; Yamada, K. Mitochondrial dysfunction, endoplasmic reticulum stress, and apoptosis in Alzheimer's disease. J. Pharmacol. Sci. 2005, 97, 312-316. [CrossRef] [PubMed]

16. Ferreiro, E.; Baldeiras, I.; Ferreira, I.L.; Costa, R.O.; Rego, A.C.; Pereira, C.F.; Oliveira, C.R. Mitochondrial- and endoplasmic reticulum-associated oxidative stress in Alzheimer's disease: From pathogenesis to biomarkers. Int. J. Cell Biol. 2012, $2012,735206$. [CrossRef]

17. Konno, T.; Melo, E.P.; Chambers, J.E.; Avezov, E. Intracellular sources of $\mathrm{ROS} / \mathrm{H}_{2} \mathrm{O}_{2}$ in health and neurodegeneration: Spot-light on endoplasmic reticulum. Cells 2021, 10, 233. [CrossRef]

18. Hoozemans, J.J.M.; Veerhuis, R.; Van Haastert, E.S.; Rozemuller, J.M.; Baas, F.; Eikelenboom, P.; Scheper, W. The unfolded protein response is activated in Alzheimer's disease. Acta Neuropathol. 2005, 110, 165-172. [CrossRef]

19. Paudel, B.; Bhattarai, H.D.; Lee, H.K.; Oh, H.; Shin, H.W.; Yim, J.H. Antibacterial activities of ramalin, usnic acid and its three derivatives isolated from the antarctic lichen ramalina terebrata. Z. Nat. C 2010, 65, 34-38. [CrossRef] [PubMed]

20. Paudel, B.; Bhattarai, H.D.; Koh, H.Y.; Lee, S.G.; Han, S.J.; Lee, H.K.; Yim, J.H. Ramalin, a novel nontoxic antioxidant compound from the Antarctic lichen Ramalina terebrata. Phytomedicine 2011, 18, 1285-1290. [CrossRef]

21. Yim, J.H.; Lee, H.K.; Paudel, B.; Bhattarai, H.D.; Kim, I.-C.; Hong, S.G.; Kim, D.K.; Lee, Y.K.; Lee, S.G.; Oh, H. Nevel Compound Ramalin, and Use Thereof. WO2010053327A2, 14 May 2010.

22. Park, B.; Yim, J.H.; Lee, H.K.; Kim, B.O.; Pyo, S. Ramalin inhibits VCAM-1 expression and adhesion of monocyte to vascular smooth muscle cells through MAPK and PADI4-dependent NF-kB and AP-1 pathways. Biosci. Biotechnol. Biochem. 2015, 79, 539-552. [CrossRef] [PubMed]

23. Kim, B.; Choi, K.M.; Yim, H.S.; Park, H.T.; Yim, J.H.; Lee, M.G. Adipogenic and lipolytic effects of ascorbic acid in ovariecto-mized rats. Yonsei Med. J. 2018, 59, 85-91. [CrossRef] [PubMed]

24. Kim, M.-K.; Yim, J.H.; Lee, D.-H.; Cho, S.K.; Yang, S.-G. Ramalin, an antioxidant compound derived from Antarctic lichen, prevents progression of liver fibrosis induced by dimethylnitrosamine (DNM) in rats. Biochem. Biophys. Res. Commun. 2018, 504, 25-33. [CrossRef]

25. Yim, J.H.; Kim, I.-C.; Kim, D.K.; Han, S.J.; Lee, H.S.; Bhattarai, H.D.; Kim, T.K.; Kim, K.S. Method for Synthesizing Ramalin and Ramalin Precursor by Using Glutamic acid Derivative and Hydroxy Aniline or Hydroxy Aniline Having Protected Hydroxy Group. WO201308959A1, 26 March 2013.

26. Pagire, S.H.; Lee, E.; Pagire, H.S.; Bae, E.J.; Ryu, S.J.; Lee, D.; Kim, M.H.; Kim, G.R.; Hwang, K.-S.; Ahn, S.; et al. Design, synthesis and biological evaluation of glutamic acid derivatives as anti-oxidant and anti-inflammatory agents. Bioorg. Med. Chem. Lett. 2018, 28, 529-532. [CrossRef]

27. Gilgun-Sherki, Y.; Melamed, E.; Offen, D. Oxidative stress induced-neurodegenerative diseases: The need for antioxidants that penetrate the blood brain barrier. Neuropharmacology 2001, 40, 959-975. [CrossRef]

28. Rankovic, Z. CNS drug design: Balancing physicochemical properties for optimal brain exposure. J. Med. Chem. 2015, 58, 2584-2608. [CrossRef]

29. Waring, M.J. Defining optimum lipophilicity and molecular weight ranges for drug candidates-Molecular weight dependent lower $\log \mathrm{D}$ limits based on permeability. Bioorg. Med. Chem. Lett. 2009, 19, 2844-2851. [CrossRef]

30. Niu, Y.; Gao, H.; Xu, F.; Wang, C.; Liu, P.; Yang, G.; Sun, Q.; Xu, P. Synthesis, in vitrobiological evaluation and molecular docking studies of benzimidamides as potential BACE1 inhibitors. Chem. Biol. Drug Des. 2012, 80, 775-780. [CrossRef] [PubMed]

31. Heppner, F.; Ransohoff, R.M.; Becher, B. Immune attack: The role of inflammation in Alzheimer disease. Nat. Rev. Neurosci. 2015, 16, 358-372. [CrossRef]

32. Coimbra, J.R.; Marques, D.F.; Baptista, S.J.; Pereira, C.M.; Moreira, P.I.; Dinis, T.C.; Santos, A.E.; Salvador, J.A. Highlights in BACE1 inhibitors for Alzheimer's disease treatment. Front. Chem. 2018, 6, 178. [CrossRef]

33. Voytyuk, I.; De Strooper, B.; Chávez-Gutiérrez, L. Modulation of $\gamma$-and $\beta$-secretases as early prevention against Alzheimer's disease. Biol. Psychiatry 2018, 83, 320-327. [CrossRef] [PubMed]

34. Prati, F.; Bottegoni, G.; Bolognesi, M.L.; Cavalli, A. Bace-1 inhibitors: From recent single-target molecules to multitarget com-pounds for Alzheimer's disease: Miniperspective. J. Med. Chem. 2018, 61, 619-637. [CrossRef]

35. Piazzi, L.; Cavalli, A.; Colizzi, F.; Belluti, F.; Bartolini, M.; Mancini, F.; Recanatini, M.; Andrisano, V.; Rampa, A. Multi-targetdirected coumarin deriv-atives: hAChE and BACE1 inhibitors as potential anti-Alzheimer compounds. Bioorg. Med. Chem. Lett. 2008, 18, 423-426. [CrossRef]

36. Di Martino, R.M.C.; De Simone, A.; Andrisano, V.; Bisignano, P.; Bisi, A.; Gobbi, S.; Rampa, A.; Fato, R.; Bergamini, C.; Perez, D.I.; et al. Versatility of the curcumin scaffold: Discovery of potent and balanced dual BACE-1 and GSK-3 $\beta$ inhibitors. J. Med. Chem. 2016, 59, 531-544. [CrossRef]

37. Tran, T.S.; Le, M.T.; Tran, T.D.; Thai, K.M. Design of curcumin and flavonoid derivatives with acetylcholinesterase and betasecretase inhibitory activities using in silico approaches. Molecules 2020, 25, 3644. [CrossRef] 
38. Tran, T.-S.; Le, M.-T.; Nguyen, T.-C.; Tran, T.-H.; Tran, T.-D.; Thai, K.-M. Synthesis, In Silico and In Vitro Evaluation for Acetylcholinesterase and BACE-1 Inhibitory Activity of Some N-Substituted-4-Phenothiazine-Chalcones. Molecules 2020, $25,3916$. [CrossRef]

39. Tran, T.-S.; Tran, T.-D.; Tran, T.-H.; Mai, T.-T.; Nguyen, N.-L.; Thai, K.-M.; Le, M.-T. Synthesis, in silico and in vitro evaluation of some flavone derivatives for acetylcholinesterase and BACE-1 inhibitory activity. Molecules 2020, 25, 4064. [CrossRef] [PubMed]

40. Capurro, V.; Busquet, P.; Lopes, J.P.; Bertorelli, R.; Tarozzo, G.; Bolognesi, M.L.; Piomelli, D.; Reggiani, A.; Cavalli, A. Pharmacological characteri-zation of memoquin, a multi-target compound for the treatment of Alzheimer's disease. PLoS ONE 2013, 8, e56870. [CrossRef] [PubMed]

41. Choi, D.Y.; Lee, Y.J.; Hong, J.T.; Lee, H.J. Antioxidant properties of natural polyphenols and their therapeutic potentials for Alzheimer's disease. Brain Res. Bull. 2012, 87, 144-153. [CrossRef]

42. Zameer, S.; Kaundal, M.; Vohora, D.; Ali, J.; Najmi, A.K.; Akhtar, M. Ameliorative effect of alendronate against intracerebroventricular streptozotocin induced alteration in neurobehavioral, neuroinflammation and biochemical parameters with emphasis on A $\beta$ and BACE-1. Neurotoxicology 2019, 70, 122-134. [CrossRef]

43. Reddy, P.H. Amyloid precursor protein-mediated free radicals and oxidative damage: Implications for the development and progression of Alzheimer's disease. J. Neurochem. 2006, 96, 1-13. [CrossRef] [PubMed]

44. Reddy, P.H.; Beal, M.F. Amyloid beta, mitochondrial dysfunction and synaptic damage: Implications for cognitive decline in aging and Alzheimer's disease. Trends Mol. Med. 2008, 14, 45-53. [CrossRef] [PubMed]

45. Lin, M.T.; Beal, M.F. Mitochondrial dysfunction and oxidative stress in neurodegenerative diseases. Nat. Cell Biol. 2006, 443, 787-795. [CrossRef] [PubMed]

46. Blois, M.S. Antioxidant determinations by the use of a stable free radical. Nature 1958, 181, 1199-1200. [CrossRef] 